IJMS 16 (2), 225-242 (2009)

\title{
FACTORS CONTRIBUTING TO FINANCIALLY DISTRESSED COMPANIES IN MALAYSIA
}

\author{
NUR ADIANA HIAU ABDULLAH \\ ROHANI MD. RUS \\ ABD. HALIM @ HAMILTON AHMAD \\ College of Business \\ Universiti Utara Malaysia
}

\begin{abstract}
By using a total of 52 distressed and non-distressed listed companies during the period 1990 to 2000, debt to total assets was found to be significant in predicting distressed companies for the multiple discriminant analysis (MDA), logit and hazard models. It appears that the higher the debt, the higher is the probability of defaulting among the financially distressed companies. MDA identified net income growth as another predictor whereas the logit and hazard model found that return on asset (ROA) to be an important predictor. Nevertheless, the sign of the ROA coefficient differred between the two models. Furthermore, company size was also identified as a contributing factor to financially distressed companies for the hazard model.
\end{abstract}

Keywords: Financial distress; MDA; Logit; Hazard model.

\begin{abstract}
ABSTRAK
Hasil daripada menggunakan 52 buah syarikat tersenarai yang mengalami dan tidak mengalami masalah kewangan di antara tahun 1990 hingga 2000, nisbah hutang kepada jumlah aset didapati signifikan untuk meramal syarikat bermasalah dengan menggunakan model analisis diskriminan pelbagai (MDA), logit dan hazard. Kajian menunjukkan semakin tinggi hutang, semakin tinggi kebarangkalian untuk tidak membayar hutang dalam kalangan syarikat yang mengalami masalah kewangan. Pertumbuhan dalam pendapatan bersih juga merupakan penentu kepada syarikat yang bermasalah apabila model MDA digunakan, manakala model logit dan hazard mendapati pulangan atas aset merupakan penentu utama. Walau bagaimana pun, tanda bagi koefisien kedua-
\end{abstract}


dua model tersebut adalah berbeza. Saiz syarikat juga dikenal pasti sebagai faktor penyumbang kepada syarikat yang mengalami masalah kewangan bagi model hazard.

Kata kunci: Masalah kewangan; MDA; Logit; Hazard model.

\section{INTRODUCTION}

The sudden currency crisis in 1997 has thrown many financially strong Malaysian companies out of business. They were not able to absorb the unexpected changes in the economy. The growing economy suddenly became alien to them when it fell into depression in a split second. As a result, many companies were forced into bankruptcy or became a financially distressed company - a condition where they were not able to pay their financial obligations because of inadequate cash flows.

Looking at the above context, it is important to understand the reasons "behind the collapse of a company. Knowing these reasons might save the company from being financially distressed and early action can be taken as a precaution. Studies in Malaysia have also looked into this area, and have used models such as the multiple discriminant analysis (MDA), the logit model, or a combination of both models. However, this study has taken a different approach where a comparison of three models-MDA, logistic regression and hazard model-was implemented.

We are trying to examine the outcome from these different techniques, and to determine which variables appear to be significant in all the three models. The remaining part of this paper is organised as follows.

"A discussion on previous studies is covered in Section Two, which is subsequently followed by an explanation of the data and research design used to answer the objectives of this study in Section Three. Section Four is an analysis of the results coming from the MDA, logistic and hazard models. The conclusion forms Section Five of this paper.

\section{LITERATURE REVIEW}

Previous bankruptcy research has identified many ratios that are important in predicting bankruptcy. However, there is no conclusive agreement of which ratios are most useful to assess the likelihood of failure. Altman (1993) noted that ratios measuring profitability, liquidity, 
solvency, and cash flow are the most significant indicators of bankruptcy. The priorities are not clear as most studies cited different ratios being the most effective indicator of bankruptcy. Moreover, most of the studies did not have an absolute test for the importance of variables (Barnes, 1987; Altman, 1993; Mohamed, Li, \& Sanda, 2001). The lack of theoretical support in choosing the appropriate variables that would predict bankruptcy have led researchers to search for other guides in variable selection. Therefore, most researchers have selected financial ratios as predictor variables based on their popularity and predictive ability in the previous bankruptcy research studies (Beaver, 1966; Altman, 1968; Ohlson, 1980; Frydman, Altman, \& Kao, 1985; Casey \& Bartczak, 1984).

Among the most popular financial ratios used by researchers are net income to total assets (Beaver, 1966; Deakin, 1972; Libby, 1975; Ohlson, 1980; Lennox, 1999), total liabilities to total assets (Beaver, 1966; Deakin, 1972; Ohlson, 1980; Zmijewski, 1984) and size (Ohlson, 1980; Lennox, 1999; Shumway, 2001). Furthermore, Ohlson (1980) added changes in net income as a factor that represents growth. Lennox (1999) utilised cash flow ratios, specifically cash to current liabilities, debtor turnover ratio, and gross cash flow ratio to explain bankruptcy in the UK. In Korea, Nam and Jinn (2000) stated that financial expenses to sales, debt coverage, and receivables turnover were important for explaining bankruptcy. In contrast to Nam and Jinn (2001), but consistent with Lennox (1999), Low, Fauzias, and Zainal Ariffin (2001) found that in Malaysia, the cash flow ratios were significant in explaining bankruptcy during the period 1996-1998; while Mohamed et al. (2001) found that the leverage ratio and efficiency ratio (total asset turnover) were found to be significant during the period 1987 to 1997. Both studies used the logit model (Low et al., 2001) and a combination of MDA and the logit model (Mohamed et al., 2001). In another study by Zulkarnain, Mohamad Ali, Anuar, and Zainal Abidin. (2001) that used the MDA model, it was found that total liabilities, to total assets, sales to current assets, cash to current liabilities, and market value to debt were significant in explaining financial distress in Malaysia during the period from 1980 to 1996. Although there were quite a number of possible financial variables available to predict bankruptcy, researchers were neither guided nor constrained by the theory for the selection of ratios (Scott, 1981). Therefore, an important criterion would be to choose ratios based on their simplicity and relevancy to the local environment (Chen \& Shimerda, 1981; Mohamed et al., 2001; Low et al., 2001).

When we looked at the development of bankruptcy prediction model, it started with the use of univariate analysis by Beaver (1966), followed by 
multivariate discriminant analysis (MDA) by Altman in 1968. Beaver's univariate analysis used individual financial ratios to predict distress. By using 79 failed and non-failed companies that were matched by industry and assets size in 1954 to 1964, his results from the prediction error tests suggested that cash flow to total debt, net income to total asset, and total debt to total assets, have the strongest ability to predict failure. These ratios differed from the MDA model proposed by Altman (1968). By utilising 33 bankrupt companies and 33 non-bankrupt companies over the period 1946 to 1964, five variables were selected on the basis that they did the best overall job in predicting bankruptcy. These were working capital to total assets, retained earnings to total assets, earnings before interest and taxes to total assets, market value of equity to book value of total debt, and sales to total assets.

Logit analysis which did not have the same assumptions as MDA was made popular by Ohlson (1980). He used 105 bankrupt companies and 2058 non-bankrupt companies from 1970 to 1976. The results showed that size, financial structure (total liabilities to total assets), performance, "and current liquidity were important determinants of bankruptcy.

Gepp and Kumar (2008) estimated Cox survival analysis model, discriminant analysis, and logit model using forward stepwise procedure and compared the classification accuracy of the three models. Results showed that the discriminant analysis model and logit model had a slightly higher number of correct classification compared with the Cox model. Chava and Jarrow (2004) used yearly and monthly observations over the period 1962 to1999 and aimed to validate the superiority of Shumway's (2001) hazard model over the models by Altman (1968) and Zmijewski (1984). Their results confirmed the more accurate prediction "capability of Shumway's hazard model.

As mentioned earlier on, several studies had been implemented in Malaysia. Zulkarnain et al. (2001) used 24 distressed and non-distressed companies from the period 1980-1996 matched according to the industry, failure year, closest asset size, and age since incorporation. The distressed companies were defined as those companies that resorted to protection under Section 176 of the Companies Act 1965 for the purpose of obtaining court protection against their creditors. Utilising the stepwise multivariate discriminant analysis to determine the discriminating variable, they compared the results from using market based variables and without market based variables. They found that total liabilities to total assets, sales to current assets, cash to current liabilities, and market 
value to debts were important determinants of corporate failures in Malaysia. Using the same definition of failure, Low et al. (2001) analysed financial distress using the logit analysis. They utilised 26 distressed companies and 42 non-distressed companies in 1988. The hold-out sample consisted of 10 companies. They found that sales to current assets, current assets to current liabilities, change in net income, cash and marketable securities to total assets were significant determinants of financial distress. However, the coefficients of the first three variables were not as expected when a significant positive coefficient prevailed. Therefore they claimed that measures of liquidity and profitability may be misleading, and concluded that only the cash flow ratio served as an indicator to detect potential failure of a company.

Mohamed et al. (2001) then compared the MDA and the logit model by using a sample consisting of 26 companies that have sought protection under section 176 of Companies Act 1965 and 79 non-distressed companies. Their results showed that when using MDA, debt ratio, and total assets turnover were found to be significant but when logit analysis was used, an additional variable, interest coverage, was also found to be significant. Thus, Mohamed et al. (2001) emphasised the importance of leverage ratio as a predictor of failure. In these studies, however, none of them used the hazard model to identify likely predictors. Hence, our study examined which among the variables were essential in predicting financially distressed companies by using the MDA, logit analysis, and hazard model.

\section{RESEARCH DESIGN}

The sample consists of both distressed and non-distressed listed companies in Bursa Malaysia. The distressed status was indicated by the appointment of receivership, restraining order under section 176, winding up petition, special administrator under Bank Negara Malaysia, and interim judicial management order as at December 2000. A total of 26 distressed companies were identified from the Bursa Malaysia daily diary. For each distressed companies, a non-distressed match was identified during the period from 1990 to $2000^{1}$. Companies were matched if they belonged to the same industry group and have the closest asset size. A one-to-one procedure is consistent with the previous studies documented in Beaver (1966), Altman (1968), and Blum (1974) and is an acceptable method in failure prediction studies. Financial data for both groups were collected from the annual reports in the Bursa Malaysia and Sultanah Bahiyah UUM library. 
Companies were excluded from the sample if they were classified under the financial and property industries. The reason for this is that their ratios were highly volatile where their businesses relied heavily on the economic condition. In addition, the interpretation of the ratios is slightly different because the nature of the income and expenses for these companies is different from that of non-financial companies.

\section{Method}

For model building, multiple discriminant analysis (MDA) which takes the form of $Z=\beta_{1} V_{a}+\beta_{2} V_{b}+\ldots+\beta_{n} V_{n}$ based on a stepwise approach was adopted to select the best discriminating variables that could predict distressed and non-distressed companies. This model would then be "compared to the logit analysis and hazard model to examine which variables could predict financially distressed companies. The logit prediction model was adopted from Ohlson (1980), Gujarati (1995, p. 554), and Joo and Jinn (2000).

$$
Z_{i}=\beta^{\prime} x_{i}+u_{i}
$$

where

$Z_{i}=$ non-distressed if $Z_{i}>0$

$Z_{\mathrm{i}}=$ distressed, otherwise

$\mathrm{x}_{\mathrm{i}}=$ companies financial ratios

$\mathrm{u}_{\mathrm{i}}=$ error term

$\mathrm{Z}_{\mathrm{i}}$ ranges from $-\infty$ to $+\infty$

The probability and likelihood function for the non-distressed company can be defined as follows:

$$
P_{i}=E\left(Y=2 \mid x_{i}\right)=\frac{1}{1+e^{-\left(\beta^{\prime} x_{i}+u_{i}\right)}}
$$

For ease of exposition, it is written as

$$
P_{i}=\frac{1}{1+e^{-Z_{i}}}
$$

where $Z_{i}=\beta^{\prime} x_{i}+u_{i}$

Equation (2) represents what is known as the (cumulative) logistic distribution function.

In order to apply the prediction model, the weights of the financial ratios were estimated in equation (1) using the financial ratios of listed 
companies. If $\mathrm{P}_{\mathrm{i}}$ represents the probability of non-distressed, which is given in equation (2), then $1-\mathrm{P}_{\mathrm{i}}$ would be the probability of being distressed. Hence,

$$
1-P_{i}=\frac{1}{1+e^{Z_{i}}}
$$

Optimal $\beta$ (weights) can be estimated where the likelihood value is maximised. The probability of being distressed is obtained by substituting $\beta$ into the cumulative probability function. A company is classified as financially distressed if the calculated probability from the logit model is more than 0.5 , otherwise it would be non-distressed.

Similar to the discriminantanalysis, a forward stepwise method is adopted in the logistic regression. This procedure would enable the predictor variables to be entered based upon their contribution to the likelihood ratio statistics. Therefore, variables that do not contribute significantly to the statistics were not entered by the procedures. Low et al. (2001) stressed that the lack of theoretical basis in selecting the independent variables was the main reason why a stepwise procedure is needed. A similar argument was made by Menard (1995) as he stated that stepwise methods were used when neither the theory nor knowledge correlates to the phenomenon. In addition, the use of a stepwise procedure would at least reduce multicollinearity problems which made it difficult to make any statistical inferences.

A discrete hazard model was applied to assess how well each variable explains the actual probability of bankruptcy in our sample. It is in the form:

$$
\phi_{i, t}=\frac{e^{\alpha(t)+\beta X_{i, t}}}{1+e^{\alpha(t)+\beta X_{i, t}}}
$$

where $\phi_{i, t}$ is the hazard function, $X$ represents a vector of explanatory variables used to forecast failure, $\alpha(t)$ is a time-varying covariates, and $\beta$ is the coefficient vector. The discrete hazard model is well suited to analyse data that consists of binary, time series, and cross-sectional observations such as bankruptcy data. The hazard model has the same likelihood function and the same asymptotic variance-covariance matrix as the logit model and therefore the estimation of the hazard model is similar to that of the logit model. However, the hazard model uses time 
varying covariates and company-year observations and consequently it is able to eliminate the sample selection bias. It would also resulted in a more efficient coefficient estimate since all available data will be used in the estimation.

In the discrete hazard model, the dependent variable is coded as 1 if company $i$ failed at time $t_{i^{\prime}}$ and equal to zero otherwise. For example, if a company had been in existence for six years and was classified under section 176 in year 6, only year 6 will have the value of 1 , the other five years will have the value of 0 indicating that the company was a healthy company during those years. Since the hazard model uses company-year data, an adjustment has to be made to the test statistics from the logit model. We divided the test statistics from the estimation by the average number of company-years per company because the correct value of $n$ for test statistics in the logit analysis is the number of companies in the data.

(1)

-The discrete hazard model uses company-year data and has several advantages (Shumway, 2001). By using all company-year observations, it is able to eliminate the sample selection bias, produces more efficient out-of-sample forecasts, and is able to adjust for risk automatically. It is also possible to track changes in bankruptcy probability since all data in each year are included in the analysis.

The independent variables used in this study can be classified according to the different set of ratios. They were leverage ratios (interest coverage and total debt to total assets), profitability ratios (net income to total assets), cash flow ratios (cash to total assets and cash to current liabilities), size (total assets employed), and growth (change in net income and change in sales). As noted by Scott (1981), many of the variables that appeared in most empirical work did not rest on any strong underlying theory, hence the use of these ratios in our study could be acceptable. These ratios were selected based on the popularity of their usage in the literature and the predictive success stated in previous research.

Financial leverage is related to bankruptcy to the extent to which a company relies on debt financing rather than equity. Measures of financial leverage are tools in determining the probability of a company defaulting on its debt contracts. Debt ratio, which is calculated by dividing total debt to total assets, provides information on a company's 
insolvency and its ability to secure additional financing for good investment opportunities. This is to ensure that creditors are protected. As for interest coverage, which is measured by dividing earnings with interest, it emphasises the ability of a company to generate enough income to cover interest expense. Beaver (1966), Deakin (1972), Ohlson (1980), Zmijewski (1984), and Mohamed et al. (2001) found that these ratios were significant determinants of corporate failure.

The Profitability ratio was represented by return on assets, computed as net income divided by total assets. This ratio is a common measure of managerial performance and is therefore vital in the study of financial distress. Libby (1975), Ohlson (1980), Lennox (1999), and Zulkarnain et al. (2001) showed that profitability is an important determinant of bankruptcy. It is expected that companies with large profits have a lower probability of bankruptcy, hence the relationship between them is negative.

In addition to the above ratios, short term solvency is also an important element to be looked into as it measures the ability of a company to meet its short term financial obligations, thus avoiding corporate failure. Cash flow ratio, represented by cash to total assets and cash to current liabilities are used as a proxy to measure short-term solvency for distressed and non-distressed companies. Lennox (1999), Low et al. (2001), and Zulkarnain et al. (2001) found that the cash flow ratios were found to be significant in their studies. It is expected that the relationship between the cash flow ratios and the probability of bankruptcy is negative - the higher the level of cash flow, the lower is the probability of bankruptcy.

Another factor that seems to discriminate between distressed and nondistressed companies is size, which is measured by total assets employed. Big companies normally have a large asset base when compared to smaller companies. Ohlson (1980) found that size was significant in discriminating between distressed and non-distressed companies. It is expected that the relationship between these two variables is negative the larger the size of a company, the lower the probability of bankruptcy. Other ratios that could probably discriminate between healthy and distressed companies are change in net income and change in sales. The rationale behind these ratios is that healthy company's net income and sales grow rapidly as compared to the distressed companies. Hence, it is expected that the greater the growth, the healthier the company. 


\section{ANALYSIS OF RESULTS}

Table 1 shows descriptive statistics of the variables used to estimate the MDA, logit, and hazard models, and a univariate analysis to identify ratios that have the highest ability to differentiate between financially distressed and non-distressed companies for the MDA/logit and hazard data sets. The results showed that variables with a mean difference that is significant at the $5 \%$ level are debt to total assets, net income to total assets, cash to current liabilities, net income growth, and current ratio for the MDA/logit sample. These ratios, with the exception of net income growth, are also found to have significant mean differences between the healthy and distressed companies for the hazard sample.

-It appeared that distressed companies relied heavily on debt, which "was approximately $84.06 \%$; whereas the build up of debt for healthy companies was only $41.13 \%$ of the MDA and logit sample. This scenario is even worst for the hazard sample as distressed companies were having a debt ratio of $247.31 \%$, which was much higher in comparison to the healthy companies that carried approximately $60.51 \%$ debt. During the period of study, the net income to total assets (ROA) was found to be negative for distressed companies with a figure of -0.122 and -0.361 for both data sets. This figure is slightly better for the healthy companies where it showed for every one ringgit of total asset, these companies were producing seven cents of net income for the MDA/logit sample whereas for the hazard sample, it showed a loss of 2.5 cents for every -ringgit of total asset.

Table 1

Mean Differences Between Distressed and Non-Distressed Companies

Panel A: MDA and Logit

\begin{tabular}{lcccc}
\hline \multicolumn{1}{c}{ Variables } & \multicolumn{2}{c}{ Means } & \multicolumn{2}{c}{ Mean Differences } \\
& Distress & Non-Distress & t- statistics & sig \\
\hline Interest coverage & 7.2603 & 278.7780 & 1.621 & 0.111 \\
Debt to total assets & 0.8406 & 0.4114 & -5.745 & $0.000^{*}$ \\
Net income to total asset & -0.1225 & 0.0729 & 5.400 & $0.000^{*}$ \\
Return on equity & -2.5019 & 0.1199 & 0.944 & 0.350 \\
Cash to total assets & 0.0209 & 0.0209 & -0.008 & 0.993 \\
Cash to current liabilities & 0.0460 & 0.0995 & 2.224 & $0.031^{*}$ \\
Net income growth & -2.4208 & 1.1081 & 4.548 & $0.000^{*}$ \\
Sales growth & 0.5076 & 0.5408 & 0.043 & 0.966 \\
CA/CL & 1.2847 & 2.2960 & 2.387 & $0.021^{*}$ \\
LnTA & 19.2558 & 18.9456 & -0.961 & 0.341 \\
\hline & & & & \multirow{2}{*}{ (continued) }
\end{tabular}


Panel B: Hazard

\begin{tabular}{lcccc}
\hline \multicolumn{1}{c}{ Variables } & \multicolumn{2}{c}{ Means } & \multicolumn{2}{c}{ Mean Differences } \\
& Distress & Non-Distress & t-statistics & sig \\
\hline Interest coverage & -.520106 & 95.214457 & .459 & .646 \\
Debt to total assets & 2.473130 & .605168 & -12.860 & $.000^{*}$ \\
Net income to total asset & -.361832 & -.024829 & 5.134 & $.000^{*}$ \\
Return on equity & .306871 & -1.274714 & -.279 & .780 \\
Cash to total assets & .018389 & .019190 & .153 & .878 \\
Cash to current liabilities & .012332 & .067988 & 2.539 & $.011^{*}$ \\
Net income growth & -.2177 & -.5477 & -.223 & .823 \\
Sales growth & -.2043 & .8033 & .606 & .545 \\
CA/CL & .337737 & 1.804498 & 2.716 & $.007^{*}$ \\
LnTA & 19.094047 & 19.035820 & -.208 & .835 \\
\hline
\end{tabular}

* significant at $\alpha=0.05$.

If we were to look at the current ratio, for every RM1 of current liabilities, there was a support of RM1.28 and RM0.34 from current assets for distressed companies in the respective MDA/logit and hazard samples. This ratio is 0.7 (MDA/logit) and 5 (hazard) times higher for healthy companies where every RM1 of current liabilities is covered with RM2.30 and RM1.80 of current assets. When it comes to cash against current liabilities, healthy companies were able to cover RM0.10 and RM0.07 for every RM1 of current liabilities in the respective MDA/logit and hazard data set. This amount is reduced to RM0.05 and RM0.01 for distressed companies, an indication that these companies would probably have difficulties in meeting their short-term financial obligations.

As expected, net income growth for distressed companies is $-242.08 \%$ and $-21.77 \%$ for the respective MDA/logit and hazard data sets; whereas healthy companies net income growth is $110.81 \%$ for the MDA/logit data, but $-54.77 \%$ for the hazard data. Surprisingly, the negative growth shown by distressed companies is smaller than the growth shown by healthy companies for the hazard data. There was not much difference in the size of those companies that were considered healthy or distressed. Some of the unexpected descriptive statistics showed us that the use of an average figure in the MDA/logit might not represent the true picture of companies' characteristics as observed in the hazard data set, which takes into consideration the time varying covariates and company-year observations.

Pearson correlations were then executed among the independent variables. The results showed that the pairwise correlations among the variables were uniformly low and insignificant, except for several ratios: 
interest cover against debt/asset, interest cover against cash/current liabilities, interest cover against CACL, net income/total asset against return on equity (ROE), cash/total asset against net income growth for the MDA/logit sample; debt/asset against net income/total asset, debt/asset against cash/current liabilities, debt/asset against net income growth, debt/asset against current ratio (CACL), net income/total asset against net income growth, cash/total asset against cash/current liabilities, cash/current liabilities against CACL, net income growth against sales growth, net income growth against CACL for both the MDA/logit and hazard data sets; net income/total asset against cash/current liabilities, net income/total asset against CACL, cash/total asset against size (lnTA), cash/current liabilities against $\operatorname{lnTA}$, sales growth against $\operatorname{lnTA}$, and CACL against lnTA for the hazard sample.

Four of the independent variables from the MDA/logit and hazard samples were highly correlated, with a value of -0.832 (MDA/logit) and (1) -0.706 (hazard) for debt to asset against net income to total asset and 0.766 (MDA/logit) and 0.741 (hazard) for cash to total asset against cash to current liabilities. In addition to this, the MDA/logit sample showed that interest cover and current ratio were also highly collinear with a value of 0.72 . In general, the correlation coefficients of the MDA/logit sample are higher than those shown by the hazard sample. The correlation coefficients would probably support the existence of a multicollinearity problem between these variables. It is noted that the identification of these Pratios is not related to any theoretical base, except for the popularity of their usage and the predictive success that came from previous research. We could simply drop these ratios, but it is likely that this remedy could probably be worse than the problem of collinearity itself.

We re-examined the independent variables to check on the seriousness of the multicollinearity problem in our data by looking at the Variance Inflating Factors (VIF). It is the ratio of a variable's actual variance to the perfect variance of zero collinearity. Refering to Table 2, the results showed that the $\mathrm{R}^{2}$ is rather low for most of the variables except for cash to current liabilities with a figure of 0.68 for the hazard data; but the $\mathrm{R}^{2}$ for the MDA/logit data is quite high for some variables such as those shown by debt to asset, net income to total asset, cash to total asset, cash to current liabilities, net income growth, and current ratio. Nevertheless, when the VIF was calculated, all the variables presented a figure below 10. Hence, we concluded that the degree of multicollinearity problem is not a threat to this study. 


\section{Table 2}

\section{Variance Inflating Factors}

Panel A: MDA and Logit

\begin{tabular}{lcc}
\hline Variables & $\mathrm{R}^{2}$ & $V I F=1 /\left(1-R_{j}^{2}\right)$ \\
\hline Interest cover against other independent variables & 0.550 & 2.222 \\
Debt/asset against other independent variables & 0.780 & 4.546 \\
Net income/total asset against other independent variables & 0.748 & 3.968 \\
Return on equity against other independent variables & 0.113 & 1.127 \\
Cash/total asset against other independent variables & 0.810 & 5.263 \\
Cash/current liabilities against other independent variables & 0.843 & 6.369 \\
Net income growth against other independent variables & 0.641 & 2.786 \\
Sales growth against other independent variables & 0.194 & 1.241 \\
CACL against other independent variables & 0.673 & 3.058 \\
lnTA against other independent variables & 0.119 & 1.135 \\
\hline
\end{tabular}

Panel A: Hazard

\begin{tabular}{lcc}
\hline Variables & $\mathrm{R}^{2}$ & $V I F=1 /\left(1-R_{j}^{2}\right)$ \\
\hline Interest cover against other independent variables & 0.011 & 1.011 \\
Debt/asset against other independent variables & 0.532 & 2.137 \\
Net income/total asset against other independent variables & 0.537 & 2.160 \\
Return on equity against other independent variables & 0.002 & 1.002 \\
Cash/total asset against other independent variables & 0.587 & 2.421 \\
Cash/current liabilities against other independent variables & 0.676 & 3.086 \\
Net income growth against other independent variables & 0.156 & 1.185 \\
Sales growth against other independent variables & 0.050 & 1.053 \\
CACL against other independent variables & 0.381 & 1.616 \\
lnTA against other independent variables & 0.040 & 1.042 \\
\hline
\end{tabular}

Table 3 reports the results of the multiple discriminant analysis. It appears that debt to total assets is more important than net income growth in predicting financially distressed companies. The latter has the least discriminating power.

\section{Table 3}

\section{Discriminant Analysis}

\begin{tabular}{lcc}
\hline Variable & Coefficient & Significance \\
\hline Debt to Total Assets & 2.764 & 0.000 \\
Net Income Growth & -0.168 & 0.000 \\
\hline
\end{tabular}

* significant at $\alpha=0.05$. 
The results of the stepwise logistic regression are presented in Panel A and Panel B of Table 4. The log likelihood statistic tests the null hypothesis where the coefficients of independent variables in the model are zero. Panel A shows that among the 10 variables, only two ratios-debt to total assets and net income to total assets - were found to be significant based on the Wald statistic. However, according to Menard (1995, p.38), a likelihood ratio (LR) test is more accurate in evaluating the statistical significance of the contribution of an independent variable to the explanation of a dependent variable. The Wald statistic normally gives an inflated standard error, which could result in a failure to reject the null hypothesis when the null hypothesis is false. Therefore, likelihood ratio test was adopted in this study as it is more reliable.

\section{Table 4}

Stepwise Logistic Regression

(C) Panel A: Variables entering the model: Wald statistic

\begin{tabular}{lccc}
\hline Variable & Coefficient & Wald & Significance \\
\hline Debt to Total Assets & 10.539 & 5.745 & $0.017^{*}$ \\
Net Income to Total Assets & -21.450 & 5.331 & $0.021^{*}$ \\
Constant & -5.789 & 4.824 & $0.028^{*}$ \\
\hline
\end{tabular}

* significant at $\alpha=0.05$.

Panel B: Variables entering the model: likelihood ratio test

\begin{tabular}{lccc}
\hline Variable & Coefficient & Change in -2 Log Likelihood & Significance \\
\hline Debt to Total Assets & 10.539 & 8.963 & $0.003^{*}$ \\
Net Income to Total Assets & -21.450 & 9.264 & $0.002^{*}$ \\
\hline
\end{tabular}

-2 Log Likelihood 45.850 with 2 degrees of freedom ( $\mathrm{p}=0.000)$.

significant at $\alpha=0.05$.

Panel B shows that the p-values of the two variables (debt to total assets and net income to total assets) are less than 0.05 , which indicate that these variables are significant in contributing to the model and in predicting financial distress. In comparison to the MDA, only debt to total assets entered the logistic regression. Furthermore, instead of net income growth, the logit model identifies return on asset as an important predictor of distressed companies. A significant negative coefficient for the return on asset variable suggests that companies with a higher proportion of net income to total assets are likely to experience financial distress. The unexpected sign contradicts those appearing in Beaver (1966), Deakin (1972), Libby (1975), Ohlson (1980), and Ward and Foster 
(1997). An explanation for this might be that the average data used in the logit model may have been affected by the financial crisis in 1997-1999 because during this period most companies had an unstable or volatile income.

The third analysis is the hazard model. Table 5 reports the determinants of financial distress. The results suggested that distressed companies in Malaysia could be determined by debt to total assets and return on asset ratios. These variables are similar to those found in the logit model. However, the positive coefficient of 2.966 for net income to total asset is in contrast to the negative coefficient found in the logit model but similar to those reported in the Western countries by Beaver (1966), Deakin (1972), Libby (1975), Ohlson (1980), and Ward and Foster (1997). This would mean that an analysis using the hazard model would probably be better as it takes into consideration of both the time varying factor and company-year observations rather than taking an average in the logit analysis. An additional variable that was found to be significant in this model is size, represented by the log of total assets. This result was consistent with a study done by Ohlson (1980) where size was one of the important determinants of bankruptcy.

Table 5

\section{Hazard Model}

Variables entering the model

\begin{tabular}{lcc}
\hline Variable & Coefficient & Significance \\
\hline Debt to Total Assets & 2.907 & $0.000^{*}$ \\
Net Income to Total Assets & 2.966 & $0.004^{*}$ \\
LnTA & 0.516 & 0.022 \\
Constant & -15.384 & $0.001^{*}$ \\
\hline
\end{tabular}

* significant at $\alpha=0.05$.

The only variable that has appeared as a consistent indicator of financially distressed companies in all the models is leverage ratio, that is, debt to total assets. Its positive coefficient of 2.764, 10.539, and 2.907 for the respective MDA, logit, and hazard models showed that financially distressed companies carry a high level of debt. The probability of defaulting on debt contracts would likely be elevated if there is a sudden down turn of income in the companies. This is consistent to the results reported by Mohamed et al. (2001) and Zulkarnain et al. (2001). 


\section{CONCLUSION}

Previous studies on Malaysian financially distressed companies have been emphasising the use of MDA and logit analysis. However, studies done in the Western countries have highlighted the inadequacies of both analysis and suggested that the hazard model may give a more accurate result than the MDA and logit models that suffer a few drawbacks with respect to the underlying assumptions. This argument has provided an opportunity for us to investigate whether such claim is true for the Malaysian companies, especially in identifying the likely predictors of distressed companies.

Our study employed 26 distressed companies with a matched sample, based on industry and size, of another 26 non-distressed companies Jisted in Bursa Malaysia. Leverage ratio was found to be an important predictor of distressed companies in all the models. Its positive coefficient shows that the higher the debt, the higher the probability of defaulting among financially distressed companies. Other determinants -that were identified to be essential in detecting distressed companies are net income growth for the MDA model, and return on asset for the logit and hazard models. For the latter variable, the sign of the coefficient differs between the logit and hazard model. Logit furnishes a negative coefficient and hazard the opposite of it. The reason for this might be due to the treatment of data by both models.

\section{END NOTES}

The data were selected in such a manner due to the changes of distress definition by the Securities Commission ever since the year 2001, where listed companies were categorised as PN4 (Practice Note 4) if they experienced inadequate level of operations as defined in Practice Note No. 10/2001 issued by KLSE; listed companies were under the purview of Danaharta Nasional Berhad and/or Corporate Debt Restructuring Committee; and listed companies under section 176 of the companies Act 1965, to the extent that they were insolvent and/or a restraining order has been granted and classified as a "rescue case" under Chapter 18 of the policies and Guidelines on Issue/Offer of Securities. With the introduction of Practice Note 4, all companies under distress status were listed here and companies under section 176 ceased to exist. As of 3 January 2005, the PN4 sector was removed and the 
existing PN4 companies were placed into PN17. Due to the rapid changes of the distress definition and the criteria needed to run the hazard model, we were constrained to the use of Section 176 of the Companies Act 1965 in the selection of the sample, that is, before Practice Note 4 was introduced.

\section{REFERENCES}

Altman, E I. (1968). Financial ratios, discriminant analysis and the prediction of corporate bankruptcy. Journal of Finance, 23, 589-609. Altman, E I. (1993). Corporate financial distress and bankruptcy. (2nd. ed.). Wiley, New York.

Barnes, P. (1987). The analysis and use of financial ratios: A Review Article. Journal of Business Finance and Accounting, 14(4), 449-461.

Beaver, W. (1966). Financial ratios as predictors of failure. Journal of Accounting Research (Supplement), 4, 71-102.

Blum, M. (1974). Failing company discriminant analysis. Journal of Accounting Research, 12, 1-25.

Casey, C., \& Bartczak, N., (1984). Cash flow: It's not the bottom line. Harvard Business Review, 4, 60- 66.

Chava, S., \& Jarrow, R. A. (2004). Bankruptcy prediction with industry effects. Review of Finance, 8, $537-569$.

Chen, K., \& Shimerda, T. (1981). An empirical analysis of useful financial ratios. Financial Management, 10, 51-60.

Deakin, E. (1972). A discriminant analysis of predictors of business failure. Journal of Accounting Research, 10, 167-179.

Frydman, H., Altman, E., \& Kao, K. (1985). Introducing recursive partitioning for financial classification: The case of financial distress. The Journal of Finance, XL(1), 269-291.

Gepp, A., \& Kumar, K. (2008). The role of survival analysis in financial distress prediction. International Research Journal of Finance and Economics, 16, $13-34$.

Gujarati, Damodar N. (1995) Basic Econometrics. McGraw-Hill International Editions, (3rd ed.). Singapore.

Joo, Ha Nam, \& Jinn, Taehong. (2000). Bankruptcy prediction: Evidence from Korea listed companies during the IMF Crisis. Journal of International Financial Management and Accounting, 11(3), 178-197.

Libby, R. (1975). Accounting ratios and the prediction of failure: Some behavioral evidence. Journal of Accounting Research, 13, 150-161.

Lennox, C. (1999). Identifying failing companies: A re-evaluation of the logit, probit and MDA approaches. Journal of Economics and Business, 51(4), 347-364. 
Low, S., Fauzias, M.N., \& Zainal Ariffin, A. (2001). Predicting corporate distress using logit model: The case of Malaysia. Asian Academy of Management Journal, 6(1), 49-62.

Menard, S. (1995) Applied logistic regression analysis. Sage University Paper series on Quantitative Applications in the Social Sciences, 07-106. Thousand Oaks, CA: Sage.

Mohamed, S., Li, A.J., \& Sanda, A.U. (2001). Predicting corporate failure in Malaysia: An application of the Logit Model to financial ratio analysis. Asian Academy of Management Journal, 6(1), 99-118.

Nam, J., Jinn, T. (2000). Bankruptcy prediction: Evidence from Korean listed companies during the IMF crisi. Journal of International Financial Management and Accounting, 11(3), 178-197.

Ohlson, J. A. (1980). Financial ratios and the probabilistic prediction of - bankruptcy. Journal of Accounting Research, 18, 109-131.

Scott, J. (1981). The probability of bankruptcy: A comparison of empirical predictions and theoretical model. Journal of Banking and Finance, 5, 317-344.

(C) Shumway, T. (2001). Forecasting bankruptcy more accurately: A simple - $\quad$ hazard model. Journal of Business, 74 (1), 101-124.

Ward, T.J., \& Foster, B.P. (1997). A note on selecting a response measure for financial distress. Journal of Business Finance and Accounting, 24, 869-879.

Zmijewski, M. E. (1984). Methodological issues related to the estimation of financial distress prediction model. Journal of Accounting Research, 22, 59-86.

Zulkarnain, M.S., Mohamad Ali, A.H., Annuar, M.N., \& Zainal Abidin, M. (2001). Forecasting corporate failure in Malaysian industrial sector firm. Asian Academy of Management Journal, 6(1), 15-30. 